\title{
Improvement of Earnings of Small Industrial Public of Alcohol Ant Sugar, 'Kolang Kaling' and Nata de coco Through Technology Usage Precise In Countryside Rasi District Ratahan Sub Provinsi Minahasa South East
}

\author{
Dr. Alfien Pandaleke \\ Lecturer, STISIP Merdeka Manado, North Sulawesi, Indonesia
}

\begin{abstract}
Compatible Countryside of district of rich Ratahan with Arenga pinnata trees applied as component of processing standard of alcohol palm sugar simply. To increase earnings hence needing evolution of production process technological usage precise. The purpose of this research was to determine the influence of Common position the extent to which and precise adjustment of the use of technology to increase the income of small industrial society.

This research applies simple and doubled linear regression analysis and mean difference test. Test statistic applied is test $t$ and test $f$. Sample is taken at random for each product type so that number of samples 60 respondents. Results of the research indicates that the position of public and precise adjustment of technology to have an effect on to earnings of small industrial public in countryside Constellation district Ratahan. Parsially hypothesis expressing that position influential to increase of earnings of acceptable small industrial public. Hypothesis expressing that adjustment of technology influential to earnings of small industrial public is refused. In simultan position variable influence of public $\left(X_{I}\right)$ and usage precise adjustment of technology $\left(\mathrm{X}_{2}\right)$ to improvement of earnings $(Y)$ visible at a real $F$ test significan so that hipótesis received. Thereby its the multiple regression formula applicable to predict earnings of public as follows: $Y^{\prime}=0.771+$ $0.775 X_{1}+0.073 X_{2}$.

To know tightly degree the relation of between visible variables at $r$ correlation coefficient 0.95 meaning the relation of position variable of public and usage precise adjustment of technology with improvement of very tightly earnings because its the correlation coefficient closing 100\%. Hereinafter coefficient of determination equal to $R_{2}=0.903$ meaning various improvement of earnings explained by various position of public and usage precise adjustment of technology $90.3 \%$ and the rest $9.7 \%$ because of other variable which has not been checked.
\end{abstract}

Hypothesis expressing position of public influential to acceptable usage precise adjustment of technology. Its the regression formula $Y^{\prime}=0.168+0.745 X_{1}$ applicable to predict usage precise adjustment of technology where every increase of position of public one scores, will increase usage precise adjustment of technology 0.745 scores.

There is difference signifikan between earningses of public before and after applying usage precise technology where earnings of public after bigger usage precise adjustment of technology compared to earnings of public before applying usage precise technology.

Keyword: Position of Public, Adjustment of Technology, Increase In Earnings.

\section{Reasoning Of Writing}

\section{Antecedent}

Compatible Countryside of District of Ratahan sub-province Minahasa the present south it is SubProvince Minahasa North Sulawesi Province South-East based on statistic (2012) expressed that public resident closing is poor 33,979 family heads, poor public 60,733 family heads, and very poor public 32,533 family heads.

To overcome the problems for the agenda overcomes poorness has been launched various enableness programs of like Construction program and improvement of earnings of small farmer and fisherman (P4K) Saving Program and Business Credit Public people prosperity (Takesra-Kukesra), Development program (PPK) Progrem overcomes poomess of urban (PsKP), Lag Countryside Supporter Infrastructure Development Program (P3DT), but result of his (its cannot assist family prosperity, because lack of knowledge and skilled so that the importance of enableness model of public to be able to process available have been resource by seeing area potency. Because of poor public amounts in South Minahasa increasingly increases causing reachs 14681 family heads. Capital owned in the form of natural resources have been available and quite a lot labour and precise technology to can be accessed but to manage the matter all requires readiness of position of public to usage precise adjustment of technology to reach target wanted. 


\title{
Formulation of Problem
}

From above dissociation hence can be formulated this research problems as follows:

1. How far position influence of public and usage precise adjustment of technology to improvement of earnings of small industrial public in countryside Rasi district Ratahan.

2. How far position influence of public tehadap usage precise adjustment of technology in countryside Rasi district Ratahan.

3. How far usage precise technology influence to improvement of earnings of small industrial public in countryside Rasi district Ratahan.

4. Is earnings of small industrial public after usage precise technology bigger than at earnings of small industrial public before usage precise technology in countryside Rasi district Ratahan?

\section{Position of Public}

\section{Book Review}

Position of Public that is is not resposif to economic opportunity because having consumptive position, likes orgy and srewed is negative attitude relationship. In line with opinion New Comb (1991) arises that direction of position is existence of relationship acting negativity and positive to an object. Not all actions or behavior of identical someone with the position to, because earning just of possibility someone is conducting action or activity which is against the position which ought or because the situation and condition obliges to entangle x'self directly although is against the willingness. (Benny and John:1998). According To Parker et all. (1995), industry gives input to public causing forms position and behavior mirror in position to work. Said position to come from Latin language aptus is meaning "conformity" or "concordance". Thurstone defines position (attitude) as affection or havings sense for or to an excitement. So position is study by giving comments at one particular object or group either popular or in bad books. Referring to the opinion Lukman, et all, (1992), attitude be evaluation of emotional feeling and tendency of profiting action or doesn't profit and go along way from someone to an object or idea.

\section{Usage Precise Technology}

Usage precise technology is strength of primary for public attitude change in increasing earnings. In line with opinion Kast \& Rosenzwarg (2002) express that science and technology would continuously be strength of primary for evolution. Technology has changed off the cuff behavior of which is not planned to become behavior that is intended and rational. Precise technology to hardly fitting in with public which indigent economically.

\section{Palm sugar}

In general palm sugar recognized in Java by the name of print sugar \& sugar ant Anonim (2006) arises bough fruit of nira is cut its the fruit is then ditinggur (lapped), swinged (2-3 days) counted 7 multiplied. Then has just entered open step langari and seen is have ready to tapped or has not. If have made ready, then digeret and marcot applies fibre of palmtree. That is by three days three nights to see produce of its the water. If produce of water have been many, then cover? conclusion fibre of palmtrees opened and lodong is attached. Entirety processed, started preparation so ready to tap requires time to think one months. Besides, equipment used process sugar also simple still. To accomodate nira/lahang from tree trunk, used bamboo bar (lodong) with length thinks one metre. After accomodated, water put into katel or frying pan and direct is cooked. Level of fire to cook nor promiscuously, must be paid attention correct.

\begin{abstract}
Alcohol
Alcohol is matter that is very often in wrong applies man, alcohol obtained from nira Alkohol to generate feeling relax, and consumer would easier to express emotion, like taste likes, sorrowful taste and enragement. If consumed to be abundant, will emerge effect : feels more freely again express x'self, becomes more emotional, opinion? sight becomes dull, totters, ability of mental experiences inhibition, that is alteration to focus attention and recall annoyed because in a state of getting drunk. (Anonim, 2006). Alcohol usually is called as captikus (alcohol $50 \%$ ) whichin processing from nira Arenga pinnata trees becomes technical alcohol $80 \%$ answer.

\footnotetext{
"Kolang-kaling"

"Kolang-kaling" is name of cemilan kenyal and has refreshing taste. Kolang kaling which in Dutch language usualy is called as glibbertjes this, made of sugar palm tree seed (Arenga pinnata) which is in the form of pipih and rubbery. To make kolang-kaling, braised formerly, then is taken its the seed to be braised for several hour(clock. Seed which have been braised the then is soaked with aqueous solution of chalk for several day so that is fermentation Anonim (2002) Kolang-kaling gives fully filled taste to man who is consuming it, besides
} 
also stops appetite and results consumption of food thus declines, so that compatible consumed as diet food (Anonim, 2002).

\section{Natade coco}

To make nata can be applied cocconut water with used starter and bacterium aceto bacterylinum. In bacterium liquid medium will grow and yields one layers is having colour is white more and more thick in layer that is recognized as nata which now circulates market is Nata made from cocconut water is recognized as Nata de coco or cocconut abstract (Anonim, 2004).

\section{Public Earnings}

According To Marx in Smelser (1990:17) express that every any public in its historical development phase stays at economics field to increase earnings. Earnings according to Ackley (1983:34) arises that earnings of individual someone can be defined as production amounts obtained from production services delivered by it to a certain time or which ontaining. Sagir (1993:29) express that level of direct interconnected earnings ably someone to fulfill fundamental requirement and social security like: food, housing, education, prosperity will influence productivity.

\section{Purpose And Research Benefit}

Based on reasoning of problems and basis theory, hence this research aim to:

1. co-signature how far usage precise adjustment of technology influence and public attitude change to earnings of small industrial public in countryside Rasi District Ratahan.

2. co-signature How far position influence to usage precise adjustment of technology and earnings of public in countryside Rasi District Ratahan.

3. co-signature is earnings of small industrial public after usage precise adjustment of technology bigger than earnings of small industrial public before usage precise adjustment of technology in countryside Rasi District Ratahan.

\section{Research Benefit}

1. For small industrial public in countryside Rasi District Ratahan can change its industrial processing technology is by applying usage precise technology to can increase the earnings.

2. For related government and institution can assist through guidance and counseling and amenity of administration for small industrial public for productive at the same time having business by applying usage precise technology.

3. For technocrat where just can give input in the form of experience of usage precise adjustment of technology which can be adopted by small industrial public in countryside Rasi District Ratahan.

4. For pebisnis can accomodate and channels result of small industrial product in countryside Rasi District Ratahan.

\section{Population and Sample}

\section{Research Method}

This research done in countryside Rasi district Ratahan. population of This research is all public labouring small industry in the form of palm sugar and mouse chop. the sample is taken at random 15 for each type effort for so that number of responders becomes 60 . Research is done by the way of survey field by using instrument of research namely questionaire prepared in advance.

\section{Research Variable}

This research variable is as follows:

1. Improvement of Earnings of Public $(\mathrm{Y})$ be earnings of small industrial public obtained from result of the industry

2. Usage Precise Adjustment Of Technology $\left(\mathrm{X}_{2}\right)$ be perception of responder about how far they receive and applies usage precise technology

3. Public Attitude Change $\left(\mathrm{X}_{1}\right)$ be perception of public about usage precise technology and public earnings

\section{Definition of Operational}

1. Improvement of Earnings of Public (Y) be earnings of small industrial public obtained from result of its the industry, with indicator:

a. Increase of earnings after applying usage precise technology.

b. Amenity of production process after applying usage precise technology.

c. Increase of result of produce of after applying usage precise technology. 
d. Increase of quality of produce of after applying usage precise technology.

e. Market access is more in demand after applying usage precise technology.

f. Improvement of production cost at factory overhead after applying usage precise technology.

g. High satisfaction to apply usage precise technology.

2. The Precise Adjustment of Technology usage $\left(\mathrm{X}_{2}\right)$ be perception of responders about the extent to which they receive and applies precise technology to be seen from the indicator:

a. Counseling and giving of theory about precise technology to hardly influences perception of small industrial public

b. Outreach and training of acurate technology followed by stake holder in group forming.

c. Training of usage precise technology done by coach at small public and industrial stake holders for powered.

d. Practice of precise technology to be done by public and stake holder under observation of coach.

e. Practice of usage precise technology my by public under upbringing stake holder.

f. Practice of precise technology to be done by public to motivation stake holder is done as according to guidance.

3. Public Attitude Change $\left(\mathrm{X}_{1}\right)$ be perception of public about usage precise technology and earnings of public seen from indicator:

a. Precise technology consumer to reduce the position can that is is not profits

b. Precise adjustment of technology to can overcome un employment

c. Applying of precise technology to can overcome poverty

d. Adjustment of technology can change consumptive position become productive

e. Adjustment of technology can change position which orgy to become simple attitude to life.

f. Precise adjustment of technology to can change drunken position of drunker.

Precise adjustment of technology to can change lazy position worked.

all variables above measured in ordinal scale

\section{Analytical methods}

At variance analysis in doubled linear regression analysis with model as follows:

$\mathrm{Y}^{\prime}=\mathrm{b}_{\mathrm{o}}+\mathrm{b}_{1} \mathrm{X}_{1}+\mathrm{b}_{2} \mathrm{X}_{2}+\mathrm{e}$

Where:

$\mathrm{Y}^{\prime}=$ improvement of earnings of public

$\mathrm{b}_{\mathrm{o}}=$ coefficient intersep

$b_{1}$ and $b_{2}=$ regression coefficient

$\mathrm{X}_{1}=$ position of public

$\mathrm{X}_{2}=$ usage precise adjustment of technology

$\mathrm{e}=$ intruder factor

Examination of fourth hypothesis by using test $t$ calculates to test difference two average of earnings before usage precise adjustment of technology and after usage precise adjustment of technology.

Data in processing by using computer peripheral system SPSS for windows.

\section{Result of Research}

\section{Result and Solution}

Improvement variable of Earnings is given [by] smallest ordinal scale of 1 and biggest . Question submitted counted 7 item so that this variable answer score calculated its the mean which can be shown to tables of following. 
Tables 1.

Number Of Responders based on flattening (Y)

\begin{tabular}{|cr|r|r|r|r|}
\hline & & & & \multicolumn{2}{c|}{$\begin{array}{c}\text { Cumulative } \\
\text { Percent }\end{array}$} \\
\hline Valid & 2,14 & Frequency & Percent & Valid Percent & 1,7 \\
& 2,29 & 2 & 1,7 & 1,7 & 5,0 \\
2,71 & 3 & 3,3 & 3,3 & 10,0 \\
3,00 & 1 & 5,0 & 5,0 & 11,7 \\
3,14 & 1 & 1,7 & 1,7 & 13,3 \\
3,29 & 3 & 5,0 & 1,7 & 18,3 \\
3,43 & 2 & 3,3 & 5,0 & 21,7 \\
3,57 & 1 & 1,7 & 3,3 & 23,3 \\
3,71 & 1 & 1,7 & 1,7 & 25,0 \\
3,86 & 1 & 1,7 & 1,7 & 26,7 \\
4,00 & 4 & 6,7 & 1,7 & 33,3 \\
4,14 & 7 & 11,7 & 6,7 & 45,0 \\
4,29 & 4 & 6,7 & 11,7 & 51,7 \\
4,71 & 11 & 18,3 & 6,7 & 70,0 \\
4,86 & 7 & 11,7 & 18,3 & 81,7 \\
5,00 & 11 & 18,3 & 11,7 & 100,0 \\
Total & 60 & 100,0 & 18,3 & \\
\hline
\end{tabular}

Answer at most at score $4.7-5$ and low score 2.14 .

Tables 2

Number Of Responders based on flattening $\left(\mathbf{X}_{1}\right)$

$\mathbf{x 1}$

\begin{tabular}{|rr|r|r|r|r|}
\hline & & & & \multicolumn{1}{c|}{$\begin{array}{c}\text { Cumulative } \\
\text { Percent }\end{array}$} \\
\hline Valid & 2,00 & Frequency & Percent & Valid Percent & 6,7 \\
& 3,00 & 10 & 6,7 & 6,7 & 23,3 \\
& 4,00 & 16,7 & 16,7 & 58,3 \\
& 5,00 & 21 & 35,0 & 35,0 & 100,0 \\
& Total & 60 & 100,0 & 41,7 & \\
\hline
\end{tabular}

Number of responders replying at most at score 5 then score 4 and lowest of score 2. Nothing that answers below (under score 1).

Tables 3.

Number Of Responders based on flattening $\left(\mathrm{X}_{2}\right)$

$\mathbf{x} 2$

\begin{tabular}{|ll|r|r|r|r|}
\hline & & & & $\begin{array}{c}\text { Cumulative } \\
\text { Percent }\end{array}$ \\
\hline Valid & 1,00 & Frequency & Percent & Valid Percent & 3,3 \\
& 2,00 & 11 & 3,3 & 3,3 & 21,7 \\
& 3,00 & 21 & 35,3 & 18,3 & 56,7 \\
4,00 & 23 & 38,3 & 35,0 & 95,0 \\
& 5,00 & 3 & 5,0 & 38,3 & 100,0 \\
& Total & 60 & 100,0 & 5,0 & \\
\hline
\end{tabular}

Number of responders which at most replying at score 4 and score 3 .

Research variable tested by its the validity and reliabiltas is position of public $\left(\mathrm{X}_{1}\right)$, usage precise adjustment of technology $\left(\mathrm{X}_{2}\right)$, and earnings of small industrial public $(\mathrm{Y})$. 
Tables 4. Validity Test and Realibilitas to Variable Income Communities (Y)

Item-Total Statistics

\begin{tabular}{|l|r|r|r|r|}
\hline & $\begin{array}{r}\text { Scale Mean if } \\
\text { Item Deleted }\end{array}$ & $\begin{array}{c}\text { Scale } \\
\text { Variance if } \\
\text { Item Deleted }\end{array}$ & $\begin{array}{c}\text { Corrected } \\
\text { Item-Total } \\
\text { Correlation }\end{array}$ & $\begin{array}{c}\text { Cronbach's } \\
\text { Alpha if Item } \\
\text { Deleted }\end{array}$ \\
\hline y1 & 25,2500 & 22,767 &, 929 &, 959 \\
y2 & 25,2667 & 22,843 &, 927 &, 959 \\
y3 & 25,1333 & 23,745 &, 911 &, 960 \\
y4 & 25,2333 & 22,792 &, 897 &, 961 \\
y5 & 25,1500 & 24,333 &, 835 &, 966 \\
y6 & 25,0833 & 23,637 &, 861 &, 964 \\
y7 & 25,1833 & 24,661 &, 829 &, 966 \\
\hline
\end{tabular}

REIiability Statistics

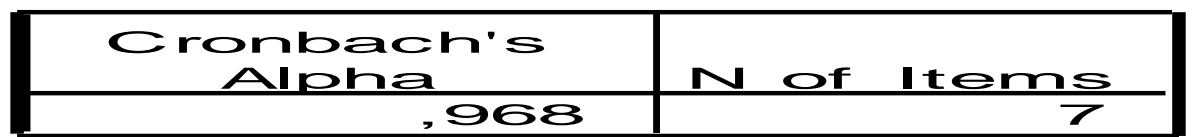

From visible above tables that public earnings reliability test (Y) equal to Cronbach's Alpha 0.968 bigger than $r=0,600$

Tables 5. Validity Test and Realibilitas to Variable Public Attitudes $\left(\mathbf{X}_{1}\right)$

\begin{tabular}{|c|c|c|c|c|}
\hline & Item-Total Statistics \\
& $\begin{array}{c}\text { Scale Mean if } \\
\text { Item Deleted }\end{array}$ & $\begin{array}{c}\text { Scale } \\
\text { Variance if } \\
\text { Item Deleted }\end{array}$ & $\begin{array}{c}\text { Corrected } \\
\text { Item-Total } \\
\text { Correlation }\end{array}$ & $\begin{array}{c}\text { Cronbach's } \\
\text { Alpha if Item } \\
\text { Delet ed }\end{array}$ \\
\hline$\times 11$ & 20,7833 & 24,410 &, 929 &, 950 \\
$\times 12$ & 20,7167 & 24,918 &, 860 &, 955 \\
$\times 13$ & 20,6500 & 24,570 &, 865 &, 955 \\
$\times 14$ & 20,5500 & 26,082 &, 825 &, 958 \\
$\times 15$ & 20,5833 & 24,756 &, 868 &, 955 \\
$\times 16$ & 20,6000 & 24,922 &, 851 &, 956 \\
$\times 17$ & 19,8167 & 25,000 &, 848 &, 956 \\
\hline
\end{tabular}

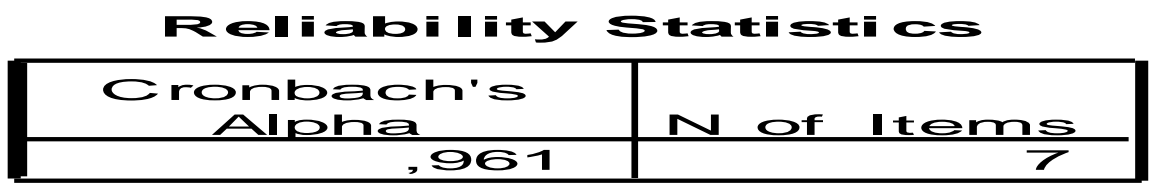

From visible above tables that position reliability test of public $\left(\mathrm{X}_{1}\right)$ equal to Cronbach's Alpha 0.961 bigger than $r=0,600$

Tables 6. Validity Test and Realibilitas to Variable Application of Appropriate Technology $\left(\mathbf{X}_{2}\right)$

Item-Total Statistics

\begin{tabular}{|c|r|r|r|r|}
\hline & $\begin{array}{c}\text { Scale Mean if } \\
\text { Item Deleted }\end{array}$ & $\begin{array}{c}\text { Scale } \\
\text { Variance if } \\
\text { Item Deleted }\end{array}$ & $\begin{array}{c}\text { Corrected } \\
\text { Item-Total } \\
\text { Correlation }\end{array}$ & $\begin{array}{c}\text { Cronbach's } \\
\text { Alpha if Item } \\
\text { Delet ed }\end{array}$ \\
\hline ×21 & 22,1333 & 13,056 &, 884 &, 890 \\
×22 & 22,2333 & 12,331 &, 874 &, 892 \\
×23 & 23,3833 & 18,492 &, 240 &, 940 \\
$\times 24$ & 22,0833 & 12,784 &, 869 &, 892 \\
$\times 25$ & 22,8000 & 16,230 &, 564 &, 922 \\
$\times 26$ & 22,4500 & 13,777 &, 991 &, 883 \\
$\times 27$ & 23,2167 & 12,889 &, 807 &, 900 \\
\hline
\end{tabular}


ReIiability Statisticos

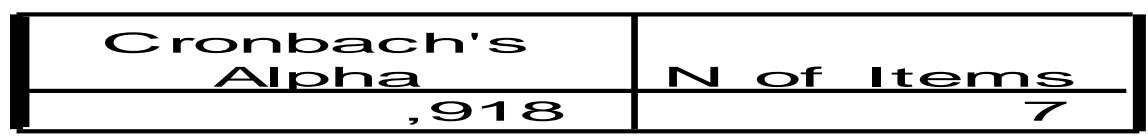

From visible above tables that usage precise adjustment of technology reliability test $\left(\mathrm{X}_{2}\right)$ equal to Cronbach's Alpha 0.918 bigger than $r=0,600$ so that expressed its the questionaire is hardly reliabel.

Tables 7. Doubled Linear Regression Analysis

Coefficients

\begin{tabular}{|c|c|c|c|c|c|c|}
\hline \multirow{2}{*}{\multicolumn{2}{|c|}{ Model }} & \multicolumn{2}{|c|}{$\begin{array}{l}\text { Unstandardized } \\
\text { Coefficients }\end{array}$} & \multirow{2}{*}{$\begin{array}{c}\text { Standardized } \\
\text { Coefficients } \\
\text { Beta }\end{array}$} & \multirow[b]{2}{*}{$t$} & \multirow[b]{2}{*}{ Sig. } \\
\hline & & B & Std. Error & & & \\
\hline \multirow[t]{3}{*}{$\overline{1}$} & (Constant) &, 771 &, 153 & & 5,053 &, 000 \\
\hline & $x 1$ & ,775 & ,054 & ,886 & 14,408 & ,000 \\
\hline & $x 2$ & ,073 & ,053 & ,084 & 1,366 & , 177 \\
\hline
\end{tabular}

a. Dependent Variable: y

From above tables parsially is visible that test $t$ calculates for position variable influence of public $\left(\mathrm{X}_{1}\right)$ 14,408 with its the probability value 0.000 smaller than alpha 0.05 . Hereinafter test $t$ calculates for usage precise adjustment of technology influence $\left(\mathrm{X}_{2}\right) 1.366$ with its the probability value 0.177 bigger than alpha 0.05 . In simultan position variable influence of public $\left(\mathrm{X}_{1}\right)$ and usage precise adjustment of technology $\left(\mathrm{X}_{2}\right)$ to improvement of earnings $(\mathrm{Y})$ visible of $\mathrm{F}$ test at its the variance analysis is as follows.

Tables 8 Variance Analysis

\begin{tabular}{|ll|r|r|r|r|r|}
\hline \multicolumn{1}{|c|}{ ANOV A $^{\mathbf{b}}$} & & \\
Model & & Sum of & & & \\
& & Squares & df & Mean Square & F & Sig. \\
\hline 1 & Regression & 34,635 & 2 & 17,317 & 264,183 &, $000^{\mathrm{a}}$ \\
& Residual & 3,736 & 57 &, 066 & & \\
& Total & 38,371 & 59 & & & \\
\hline
\end{tabular}
a. Predictors: (Constant), x2, x1

b. Dependent Variable: y

Showing above tables is calculate $\mathrm{F}$ test 264.183 with its the probability 0.000 smaller than alpha 0.005 .

Tables 9 Correlation Coefficient and Determination

\begin{tabular}{|l|r|r|r|r|}
\multicolumn{8}{c|}{ Model Summary } \\
\hline Model & $\mathrm{R}$ & $\mathrm{R}$ Square & $\begin{array}{c}\text { Adjusted } \\
\mathrm{R} \text { Square }\end{array}$ & $\begin{array}{c}\text { Std. Error of } \\
\text { the Estimate }\end{array}$ \\
\hline 1 &, $950^{\mathrm{a}}$ &, 903 &, 899 &, 25603 \\
\hline
\end{tabular}

a. Predictors: (Constant), $\times 2, \times 1$

Hereinafter coefficient of determination equal to $\mathrm{R}_{2}=0.903$.

\section{Examination method}

Technical alcohol based on precise adjustment of technology to be obtained from distillation process yielded by high alcohol rate reachs $80 \%$ sd 100\% (formerly stamped mouse with level of alcohol 35-45\%. Kolang-kaling is food-stuff like fruit of fresh, has refreshing taste. Nata is food type which have been long enough in recognizing in Philipina and Untuk makes nata can be applied cocconut water with and seed nata or starter and bacterium aceto bacter ylinum. Palm sugar is sweetener food-stuff made from nira pound aren/enau. All in produc yielded by small industrial public in countryside Rasi Kecamatan Ratahan through usage precise adjustment of technology. From result of research about Jumlah Responden based on flattening Skor answer variable improvement of earnings public (Y) result of his its indicating that most small industrial public experiences improvement of earnings which caused by usage precise adjustment of technology where public sudh follows socialisation then they to understand and practices is above all for palm sugar industry and the mothers umah doorstep which can open work field by processing nata decoco so that the mothers can open work 
field of addition to be able to increase the earnings according to result of recearct at tables 1 Answer at most at score 4.7-5 and low score 2.14.

This thing indicates that most small industrial public experiences improvement of earnings which caused by usage precise adjustment of technology. Hereinafter distribution of responder based on their position to improvement of its the earnings is visible at tables 2 Number of responders replying at most at score 5 then score 4 and lowest of score 2 . Nothing that answers under score 1. this thing also shows position of a real public height to improvement of the earnings. Hereinafter distribution of responder based on usage precise adjustment of technology to improvement of its the earnings is visible at tables 3 Number of responders which at most replying at score 4 and score 3 . Fewest at score 1 . Highest score namely 53 man only who is replying it.

From result of research of public earnings reliability test (Y) equal to Cronbach's Alpha 0.968 bigger than $r=0,600$ so that expressed the questionaire is hardly reliabel. To test validity for all question of earnings of public (Y) what consisted of 7 item also expressed is valid because item-total its the correlation bigger than 0.300 .

From visible above 4 tables that position reliability test of public $\left(\mathrm{X}_{1}\right)$ equal to Cronbach's Alpha 0.961 bigger than $r=0,600$ so that expressed its the questionaire is hardly reliabel. To test validity for all question of position of public $\left(\mathrm{X}_{1}\right)$ what consisted of 7 item also expressed is valid because item-total its the correlation bigger than 0.300 .

From visible above tables that usage precise adjustment of technology reliability test $\left(\mathrm{X}_{2}\right)$ equal to Cronbach's Alpha 0.918 bigger than $r=0,600$ so that expressed its the questionaire is hardly reliabel. To test validity for all question of position of public $\left(\mathrm{X}_{1}\right)$ what consisted of 7 item also expressed is valid because itemtotal the correlation bigger than 0.300 .

Hereinafter to know position influence of public $\left(\mathrm{X}_{1}\right)$ and usage precise adjustment of technology $\left(\mathrm{X}_{2}\right)$ to public earnings (Y) parsially is done test $\mathrm{t}$ at doubled linear regression analysis which result of his(its is from above 5 tables parsially is visible that test $t$ calculates for position variable influence of public $\left(\mathrm{X}_{1}\right)$ 14,408 with the probability value 0.000 smaller than alpha 0.05 so that hypothesis expressing that position influential to increase of earnings of acceptable small industrial public. Hereinafter test $t$ calculates for usage precise adjustment of technology influence $\left(\mathrm{X}_{2}\right) 1.366$ with the probability value 0.771 bigger than alpha 0.05 so that hypothesis expressing that adjustment of technology influential to earnings of small industrial public is refused.

In simultan position variable influence of public $\left(\mathrm{X}_{1}\right)$ and usage precise adjustment of technology $\left(\mathrm{X}_{2}\right)$ to improvement of earnings (Y) visible of $F$ test at the variance analysis at Tabel showing above 6 is calculate $F$ test 264.183 with the probability 0.000 smaller than alpha 0.005 so that hypothesis expressing that position of public $\left(\mathrm{X}_{1}\right)$ and usage precise adjustment of technology $\left(\mathrm{X}_{2}\right)$ influential to improvement of earnings $(\mathrm{Y})$ acceptable. To know tightly degree the relation of between visible variables at $\mathrm{r}$ correlation coefficient 0.95 meaning the relation of position variable of public and usage precise adjustment of technology with improvement of very tightly earnings because the correlation coefficient closing one hundred $\%$.

Hereinafter at tables 7 coefficient of determination equal to $R_{2}=0.903$ meaning various Parsially hypothesis expressing that position influential to increase of earnings of acceptable small industrial public. Hypothesis expressing that adjustment of technology influential to earnings of small industrial public is refused. In simultan position variable influence of public $\left(\mathrm{X}_{1}\right)$ and usage precise adjustment of technology $\left(\mathrm{X}_{2}\right)$ to improvement of earnings (Y) visible at a real $\mathrm{F}$ test significan so that hipótesis received. Thereby the multiple regression formula applicable to predict earnings of public as follows: $\mathrm{Y}^{\prime}=0.771+0.775 \mathrm{X}_{1}+0.073 \mathrm{X}_{2}$. To know tightly degree the relation of between visible variables at $r$ correlation coefficient 0.95 meaning the relation of position variable of public and usage precise adjustment of technology with improvement of very tightly earnings because the correlation coefficient closing one hundred \%. Hereinafter coefficient of determination equal to $\mathrm{R} 2=0.903$ meaning various improvement of earnings explained by various position of public and usage precise adjustment of technology $90.3 \%$ and the rest $9.7 \%$ because of other variable which has not been checked.

Hypothesis expressing position of public influential to acceptable usage precise adjustment of technology. Its the regression formula $\mathrm{Y}^{\prime}=0.168+0.745 \mathrm{X} 1$ applicable to predict usage precise adjustment of technology where every increase of position of public one scores, will increase usage precise adjustment of technology 0.745 scores.

There is difference si gnifikan between earningses of public before and after applying usage precise technology where earnings of public after bigger usage precise adjustment of technology compared to earnings of public before applying usage precise technology.

From above dissociation hence all hypothesises submitted at this research received causing needs continuation lebiih study of usage precise adjustment of technology in countryside Rasi district Ratahan. improvement of earnings explained by various position of public and usage precise adjustment of technology $90.3 \%$ and the rest $9.7 \%$ because of other variable which has not been checked. 


\section{Conclusion}

From dissociation which has been told at chapters before all hence inferential some things as follows.

1. Technical alcohol based on precise adjustment of technology to be obtained from distillation process yielded by high alcohol rate reachs $80 \%$ - 100\% (formerly stamped mouse with level of alcohol 35-45\%. Kolang-kaling is food-stuff like fruit of fresh, has refreshing taste. Nata is food type which have been long enough in recognizing in Philipina and for makes nata can be applied cocconut water with and seed nata or starter and bacterium aceto bacter ylinum. Palm sugar is sweetener food-stuff made from nira pound arenga pinnata. All this product yielded by small industrial public in countryside Rasi District Ratahan through usage precise adjustment of technology.

2. Parsially hypothesis expressing that position influential to increase of earnings of acceptable small industrial public. Hypothesis expressing that adjustment of technology influential to earnings of small industrial public is refused. In simultan position variable influence of public $\left(X_{1}\right)$ and usage precise adjustment of technology (X2) to improvement of earnings ( $\mathrm{Y}$ ) visible at a real $\mathrm{F}$ test significan so that hipótesis received. Thereby the multiple regression formula applicable to predict earnings of public as follows: $\mathrm{Y}^{\prime}=0.771+0.775 \mathrm{X} 1+$ $0.073 \mathrm{X} 2$.

3. To know tightly degree the relation of between visible variables at $r$ correlation coefficient 0.95 meaning the relation of position variable of public and usage precise adjustment of technology with improvement of very tightly earnings because the correlation coefficient closing one hundred $\%$.

4. Hereinafter coefficient of determination equal to $R_{2}=0.903$ meaning various improvement of earnings explained by various position of public and usage precise adjustment of technology $90.3 \%$ and the rest 9.7 $\%$ because of other variable which has not been checked.

5. Hypothesis expressing position of public influential to acceptable usage precise adjustment of technology. Its the regression formula $\mathrm{Y}^{\prime}=0.168+0.745 \mathrm{X} 1$ applicable to predict usage precise adjustment of technology where every increase of position of public one scores, will increase usage precise adjustment of technology 0.745 scores.

6. There is difference signifikan between earningses of public before and after applying usage precise technology where earnings of public after bigger usage precise adjustment of technology compared to earnings of public before applying usage precise technology. From above dissociation hence all hypothesises submitted at this research received causing needs continuation lebiih study of usage precise adjustment of technology in countryside Rasi district Ratahan.

\section{Suggestion}

From above conclusion, hence suggested some things as follows:

1. Need to be done continuation research, because there are still rest of natural resources that is is not applied that is through small Industri usage precise technology of Virgine Coconut Oil and Rhum so that increase earnings of public.

2. Need to be done continuation research of about management of health permission that that this small industry will be managed to become Home Industri so that there are attitude change.

\section{Bibliography}

[1] Arsyat, 1992. Development Economics of Elephant University Mada Yogyakarta

[2] Akley Garder, 1983. Macroeconomicses, Translated by Paul Sihotang Universitas Indonesia (UI ORESS) Jakarta.

[3] ASLI L. Big Dictionary of Second Edition Indonesia Language, Eight Die of Hall Wirasari Jakarta.

[4] Abdullah NS, 1981. Economics Deliverer, PP3K BANDUNG.

[5] Anonim, 2007. KPN LGI com ---- http//www kpn lgiu com/@/html

[6] Anonim, 2002. Nirasari __ http/www javasugr/com/ni

[7] Anonim, 2006. BPTTP UNIVERSITAS KATOLIK ATMAJAYA -- httpwww atmajaya.ac.id contentasp/=8\&id=849

[8] Anonom, 2002. Wiki Pedia ----- http://id.wikipedia.org/wiki/kolang-kaling

[9] Anonim, 2002. Hak Public? People Mind Creature Gyber Media. http://www.pikiran-rakyat.com/cetak/1004/21/cakrawala/

[10] Anonim, 2007. BPTP LAMPUNG --- Enamel: bptp lampung@telkom net

[11] Anonim, 2006. Wikipedia ----- http/id/Wikipedia org/Wiki/Teknologi Guna

[12] Anonim, 2007. Wikipedia ----- http/id/Wikipedia org/Wiki/Teknologi

[13] Anonim, 2007. Earnings Wikipedia ----- http/id/Wikipedia org Wiki Earnings

[14] Koentjaraningrat, 1995, Culture of Mentaliteit and Development, PT Gramedia Jakarta

[15] Kartasapoetra G. 1985, Sociology Induastri, Constructs Aksara Jakarta.

[16] Marat, 1994, Position of Its the Evolution Man And measurement, Chalia Indonesia Jakarta.

[17] New Comb, 1981, Social psychology, Diponegoro Bandung

[18] Parker S.M.R.M. Brownian, J Child MA. Smith, Sosiologi Industri Rineke Cipta Jakarta

[19] Rahardjo Dawan, 1985, Orthogonal Transformation of Construction of Industrialization of Opportunity of Job (Activity UI PRESS JAKARTA.

[20] Smelser J. 1987, Sosiologin Economics, Publisher Wirasari Jakarta.

[21] Soelaiman 1986, Base Culture Science, Jakarta. 